\title{
PENGARUH BRISK WALKING EXERCISE TERHADAP PENURUNAN TEKANAN DARAH PADA LANSIA
}

\section{The Effect of Brisk Walking Exercise on Blood Pressure Reduction In Elderly}

\author{
Sri Mulia ${ }^{1}$, Dian Istiana ${ }^{2}$, Dewi Nur Sukma Purqoti ${ }^{3}$ \\ ${ }^{1}$ Mahasiswa Program Studi S1 Keperawatan, STIKes Yarsi Mataram, Mataram, Indonesia \\ ${ }^{2}$ Departemen Keperawatan Jiwa dan Komunitas, STIKes Yarsi Mataram, Mataram, Indonesia \\ ${ }^{3}$ Departemen Keperawatan Medikal Bedah, STIKes Yarsi Mataram, Mataram, Indonesia \\ Korespondensi: alhyamulhia12@gmail.com
}

\begin{abstract}
ABSTRAK
Hipertensi merupakan salah satu masalah kesehatan pembuluh darah yang ditandai dengan peningkatan tekanan darah. Hipertensi adalah suatu keadaan dimana seseorang mengalami tekanan darah diatas normal yang mengakibatkan peningkatan angka kesakitan (morbiditas) dan angka kematian (mortalitas). Tujuan penelitian adalah untuk mengetahui pengaruh brisk walking excercise terhadap penurunan tekanan darah. Desain penelitian menggunakan pendekatan eksperimen dengan one group pretest-posttest. Jumlah populasi dalam penelitian ini adalah 60 dan 18 orang direkrut sebagai sampel. Teknik pengambilan sampel menggunakan purposive sampling. Analisis data menggunakan paired t-test. Hasil penelitian ini menunjukkan adanya pengaruh brisk walking excercise terhadap tekanan darah sistolik dan diastolik dengan nilai p masing-masing 0,000 (sistolik) dan 0,003 (diastolik). Dapat disimpulkan bahwa ada pengaruh antara brisk walking excercise terhadap penurunan tekanan darah pada lansia dengan hipertensi. Hasil penelitian ini diharapkan dapat dijadikan salah satu intervensi keperawatan dalam tatalaksana pasien hipertensi.
\end{abstract}

Kata Kunci: brisk walking exercise, hipertensi, lansia.

\section{ABSTARCT}

Hypertension is a blood vessel health problem characterized by an increase in blood pressure. Hypertension is a condition in which a person experiences blood pressure above normal which results in increased morbidity and mortality. The aim of the study was to determine the effect of brisk walking excercise on blood pressure reduction in elderly. The research design used an experimental approach with one group pretest-posttest. The population in this study was 60 and 18 people were recruited as samples. The sampling technique used purposive sampling. Data analysis using paired t-test. The results of this study indicate the effect of walking excercise brisk on systolic and diastolic blood pressure with $p$ values of 0.000 (systolic) and 0.003 (diastolic), respectively. It can be concluded that there is an effect between Brisk walking excercise on reducing blood pressure in the elderly with hypertension. The results of this study are expected to be used as a nursing intervention in the management of hypertensive patients.

Keywords: brisk walking exercise, hypertension, elderly 


\section{PENDAHULUAN}

Hipertensi merupakan peningkatan tekanan darah yang menimbulkan gejala yang berlanjut untuk suatu target organ, seperti stroke untuk otak, penyakit jantung koroner untuk pembuluh darah jantung dan otot jantung. Penyakit ini menjadi masalah utama dalam kesehatan masyarakat yang ada di indonesia maupun di beberapa negara di dunia. Diperkirakan sekitar $80 \%$ kenaikan kasus hipertensi terutama di negara berkembang tahun 2025, dari jumlah 639 juta kasus di tahun 2000 , menjadi 1,15 milyar di tahun 2025. Prediksi ini didasarkan pada jumlah angka penderita hipertensi dan pertambahan penduduk saat ini (Armilawaty, Amalia, \& Amiruddin, 2007).

Berdasarkan data WHO, diperkirakan 1,13 miliar orang menderita hipertensi (WHO, 2019). Diperkirakan sampai tahun 2025 tingkat terjadinya tekanan darah tinggi akan bertambah 60\%, dan akan mempengaruhi 1,56 milyar penduduk di seluruh dunia (Kementerian Kesehatan RI, 2016). Hasil Riskesdas Indonesia tahun 2018 menunjukkan sebagian besar kasus hipertensi di masyarakat belum terdiagnosis. Hal ini terlihat dari hasil pengukuran tekanan darah pada usia $>18$ tahun ditemukan prevalensi hipertensi di indonesia sebesar $34,1 \%$ dimana hanya $7,2 \%$ penduduk yang sudah mengetahui memiliki hipertensi dan hanya $8,8 \%$ kasus yang minum obat hipertensi (Badan Penelitian dan Pengembangan Kesehatan, 2018)

Prevalensi penderita hipertensi dengan hasil pengukuran bila tekanan darah sistolik $\geq 140 \mathrm{mmHg}$ dan tekanan darah diastolik $\geq 90 \mathrm{mmHg}$ usia $\geq 18$ tahun di Provinsi NTB diperkirakan sebanyak 358.110 jiwa dan yang mendapatkan pelayanan sebesar 56.107 jiwa $(15,67 \%)$. Jumlah penderita hipertensi tahun 2018 di puskesmas sekota mataram berjumlah 37.190 kasus (Dinas Kesehatan Provinsi NTB, 2019). Berdasarkan data yang didapatkan dari Puskesmas Ampenan Kota Mataram di tahun 2017 jumlah penduduk usia $\geq 18$ tahun wilayah puskesmas sebesar 25.253 jiwa, dan yang dilakukan pengukuran tekanan darah sebanyak 6.338 jiwa $(25,10 \%)$. Sedangkan yang menderita hipertensi sebanyak 1.750 kasus (6,93\%). Kemudian pada tahun 2018 jumlah penduduk usia $\geq 18$ tahun meningkat sebanyak 38.628 jiwa dan yang dilakukan pengukuran tekanan darah sebesar 7.028 jiwa $(36,02 \%)$. Sedangkan jumlah penderita hipertensi juga meningkat sebesar 2.610 kasus $(6,76 \%)$ dari tahun lalu. Didapat data bahwa Kelurahan Bintaro merupakan wilayah yang banyak penduduknya menderita hipertensi yaitu sebesar 746 kasus (8,51\%). Sedangkan Kelurahan Dayan Peken 736 kasus (6,92\%), Kelurahan Ampenan Tengah 638 kasus (5,54\%), dan Kelurahan Ampenan Utara 490 kasus $(6,36 \%)$. Terdapat dua desa di Kelurahan Bintaro yaitu Pondok Perasi dan Bugis. Data jumlah penderita hipertensi bulan September sampai dengan November tahun 2019 di Kelurahan Bintaro Desa Pondok Perasi sebanyak 60 orang, sedangkan di Desa Bugis sebanyak 20 orang (Puskesmas Ampenan, 2019).

Berdasarkan penelitian epidemiologi, ditemukan bahwa tekanan darah meninggi dapat terjadi karena meningkatnya umur, hipertensi menjadi masalah karena sering ditemukan pada lanjut usia dan menjadi faktor utama payah jantung dan penyakit jantung koroner. Lebih dari separuh kematian disebabkan oleh penyakit jantung dan serebrovaskuler diatas 60 tahun (Nugroho, 2012). Olahraga yang dianjurkan bagi lansia, adalah olahraga dengan gerakan yang melibatkan pelatihan pernafasan dan jantung, melatih kekuatanotot, kekuatan sendi, serta bersifat rekreasi, sehingga tidak menimbulkan rasa jenuh untuk lansia (Muhith \& Siyoto, 2016).

Penatalaksanaan hipertensi dapat dilakukan dengan metode non farmakologis. Salah satu bentuk metode non-farmakologis yaitu brisk walking exercise, yang merupakan latihan aktivitas sedang pada pasien hipertensi dengan menggunakan tehnik jalan cepat selama 20 30 menit dengan rata-rata kecepatan 4-6 $\mathrm{km} / \mathrm{jam}$. Latihan ini cukup efektif meningkatkan kapasitas denyut jantung, merangsang kontraksi otot, memecahkan glikogen dan meningkatkan oksigen jaringan. Latihan ini dapat juga mengurangi 
terbentuknya plak melalui peningkatan penggunaan lemak dan peningkatan penggunaan glukosa (Kowalski, 2010).

Berdasarkan hasil studi pendahuluan dengan melakukan wawancara lima orang lansia dengan hipertensi, hasil studi pendahuluan didapatkan bahwa dari lima orang penderita hipertensi tersebut sebanyak $20 \%$ biasa melakukan aktivitas fisik ringan dan $80 \%$ tidak memiliki kebiasaan olahraga yang baik dan jarang melakukan aktivitas fisik. Dari latar belakang diatas dapat disimpulkan bahwa lansia dengan penderita hipertensi masih sangat kurang dalam melakukan kebiasaan olahraga dan aktivitas fisik seperti berjalan, sehingga peneliti tertarik untuk meneliti Pengaruh brisk walking exercise terhadap penurunan tekanan darah pada lansia di wilayah kerja puskesmas ampenan.

\section{TUJUAN PENELITIAN}

Penelitian ini bertujuan untuk mengetahui pengaruh brisk walking exercise terhadap penurunan tekanan darah pada lansia di wilayah kerja Puskesmas Ampenan.

\section{METEDOLOGI PENELITIAN}

Desain

Desain penelitian suatu yang sangat penting dalam penelitian, memungkinkan untuk pengontrolan maksimal beberapa faktor yang dapat mempengaruhi akurasi suatu hasil (Nursalam, 2016). Desain penelitian menggunakan eksperimental dengan pendekatan one group pretest posttest.

\section{Populasi dan Sampel}

Populasi dalam penelitian ini adalah lansia yang menderita hipertensi terdiri dari 60 orang di desa Pondok Perasi wilayah kerja Puskesmas Ampenan dengan teknik sampling non-probability sampling dengan purposive sampling. Kriteria inklusi sampel dalam penelitian ini antara lain bersedia menjadi responden, dapat berjalan dengan baik dan tidak memiliki komplikasi. Sedangkan kriteria eksklusi dalam penelitian ini adalah memiliki gangguan penglihatan dan/atau buta, tidak koperatif selama prosedur dilakukan, dan mengalami masalah kejiwaan.

\section{Tempat dan Waktu Penelitian}

Penelitian ini dilaksanakan di Wilayah Kerja Puskesmas Ampenan Desa Pondok Perasi Kecamatan Bintaro, Kota Mataram. Pengambilan data dilakukan selama 1 minggu.

Instrumen dan Prosedur Pengukuran Instrumen yang digunakan untuk pengukuran tekanan darah yaitu sphygmomanometer. Pengukuran tekanan darah dilakukan sebelum responden melakukan brisk walking exercise. Selanjutnya selama 1 minggu responden diobservasi melakukan brisk walking exercise. Setelah 1 minggu, kemudian dilakukan pengukuran tekanan darah (post test).

\section{Analisa Data}

Pengolahan data dilakukan dengan melakukan editing, coding, entry, cleaning dan tabulating pada master tabel yang telah disusun. Data yang telah ditabulasi selanjutnya dilakukan uji kenormalan data. Analisa data menggunakan paired t-test.

\section{Intervensi}

Seluruh responden yang terlibat dalam penelitian ini diberikan latihan brisk walking selama 4 minggu. Latihan dilakukan setiap 1 minggu sekali selama 20 menit.

\section{HASIL PENELITIAN}

Hasil penelitian akan dijelaskan sebagai berikut:

Tabel 1

Karakteristik Responden ( $\mathrm{n}=18)$

\begin{tabular}{lcc}
\hline $\begin{array}{c}\text { Karakteristik } \\
\text { responden }\end{array}$ & $\begin{array}{c}\text { Frekuensi } \\
\text { (f) }\end{array}$ & $\begin{array}{c}\text { Persentase } \\
(\%)\end{array}$ \\
\hline Usia & & \\
$45-59$ & 16 & 88,9 \\
$60-70$ & 2 & 11,1 \\
\hline Tingkat & & \\
Pendidikan & & \\
Tidak sekolah & 3 & 16,7 \\
SD & 14 & 77,8
\end{tabular}


Sri Mulia, dkk : Pengaruh Brisk Walking Exercise terhadap Penurunan Tekanan Darah pada Lansia

\begin{tabular}{lcc} 
SMP & 1 & 5,5 \\
SMA & 0 & 0 \\
$P T$ & 0 & 0 \\
\hline Jenis Kelamin & & \\
$\quad$ Laki-laki & 0 & 0 \\
$\quad$ Perempuan & 18 & 100 \\
\hline Derajat & & \\
Hipertensi & & \\
Stadium 1 & 15 & 83,3 \\
Stadium 11 & 3 & 16,7 \\
\hline
\end{tabular}

Berdasarkan tabel 1 diketahui karakteristik berdasarkan usia yang paling dominan adalah antara 45-59 tahun sebanyak 16 orang $(88,9 \%)$. Dilihat dari tingkat pendidikan paling dominan yaitu berpendidikan SD sebanyak 14 orang $(77,8 \%)$. Berdasarkan jenis kelamin semua perempuan $(100 \%)$. Berdasarkan derajat hipertensi yang paling dominan pada stadium 1 sebanyak 15 orang $(83,3 \%)$.

\section{Tabel 2}

Pengaruh Brisk Walking Exercise Terhadap Penurunan Tekanan Darah Sistolik $(n=18)$

\begin{tabular}{|c|c|c|c|}
\hline \multicolumn{2}{|c|}{ Variabel } & \multirow{2}{*}{$\begin{array}{l}\mathbf{N} \\
5\end{array}$} & \multirow[t]{2}{*}{$\rho$ value } \\
\hline \multirow{3}{*}{$\begin{array}{l}\text { Sistolik } \\
\text { Pretest }\end{array}$} & 140 & & \\
\hline & 150 & 10 & \multirow{4}{*}{.000} \\
\hline & 160 & 3 & \\
\hline Sistolik & 130 & 11 & \\
\hline Postest & 140 & 7 & \\
\hline
\end{tabular}

Berdasarkan tabel 2. menjelaskan hasil uji paired $t$ nilai tekanan darah sistolik setelah diberikan perlakuan brisk walking exercise yaitu $\rho$ value 0,000 , ada pengaruh yang signifikan dari pemberian brisk walking exercise terhadap penurunan tekanan darah sistolik pada pasien lansia dengan hipertensi.

Tabel 3

Pengaruh Brisk Walking Exercise Terhadap Penurunan Tekanan Darah Diastolik $(\mathrm{n}=18)$

\begin{tabular}{|c|c|c|c|}
\hline \multicolumn{2}{|c|}{ Variabel } & \multirow{2}{*}{$\begin{array}{l}\mathbf{N} \\
1\end{array}$} & \multirow[t]{2}{*}{$\rho$ value } \\
\hline \multirow{4}{*}{$\begin{array}{c}\text { Distolik } \\
\text { Pretest }\end{array}$} & 80 & & \\
\hline & 90 & 9 & \multirow{5}{*}{.003} \\
\hline & 100 & 6 & \\
\hline & 110 & 2 & \\
\hline \multirow{2}{*}{$\begin{array}{l}\text { Distolik } \\
\text { Postest }\end{array}$} & 80 & 5 & \\
\hline & $\begin{array}{c}90 \\
100\end{array}$ & $\begin{array}{c}12 \\
1\end{array}$ & \\
\hline
\end{tabular}

Berdasarkan tabel 3. di atas menjelaskan hasil paired t-test nilai ratarata tekanan darah distolik setelah diberikan perlakuan brisk walking exercise yaitu dengan $\rho$ value 0,003 , ada pengaruh yang signifikan dari pemberian brisk walking exercise terhadap penurunan tekanan darah distolik pada pasien lansia dengan hipertensi.

\section{PEMBAHASAN}

Berdasarkan hasil uji statistik paired$t$ untuk data tekanan darah sistolik dan diastolik pada responden lansia hipertensi yang diberikan brisk walking exercise, didapatkan nilai $\mathrm{p}<0,05$ untuk tekanan darah sistolik dan tekanan darah diastolik. Hasil ini menunjukkan terdapat pengaruh yang bermakna antara sebelum dan sesudah diberikan perlakuan brisk walking exercise selama 20 menit sebanyak 3 kali perlakuan dalam waktu 1 minggu.

Penelitian ini juga sejalan dengan hasil penelitian Suranti (2017), memberikan hasil serupa terdapat penurunan tekanan darah sistolik dan diastolik yang bermakna setelah diberikan brisk walking exercise pada pasien hipertensi. Pradono (2010) mengemukakan bahwa hipertensi 90\% belum diketahui secara pasti penyebabnya, namun dibeberapa penelitian ada beberapa faktor yang dapat mempengaruhi terjadinya hipertensi yaitu merokok, minuman beralkohol, berat badan berlebih serta stress. Faktor risiko yang tidak dapat dikendalikan pada hipertensi seperti jenis kelamin, keturunan, ras dan usia. Sedangkan faktor risiko yang dapat dikendalikan seperti kurang olahraga atau aktivitas, obesitas, minum kopi, merokok, sensitivitas natrium, alkoholisme, kadar kalium rendah, pola makan, pekerjaan, pendidikan dan stress (Andria, 2013).

Brisk walking exercise merupakan salah satu jenis olahraga aerobik tingkat sedang, yang membuat otot dan persendian tetap fleksibel, mengurangi kekakuan otot, membersihkan darah dengan meningkatkan efisiensi paru, melancarkan sirkulasi darah, menurunkan stress dan meringankan pikiran, mengaktifkan dan meremajakan 
kulit, menyebabkan keluarnya keringat secara normal (Wijayakusuma, 2008).

Penurunan tekanan darah pada hipertensi terjadi karena pembuluh darah mengalami pelebaran dan terjadi relaksasi pembuluh darah yang menyebabkan penurunan tekanan darah. Dalam hal ini olahraga aerobik yang dilakukan secara rutin dapat mengurangi tahanan perifer pembuluh darah. Mekanisme penurunan tekanan darah juga diakibatkan oleh aktivitas pompa jantung yang berkurang. Otot jantung individu yang berolahraga secara rutin lebih kuat dibandingkan dengan individu yang jarang berolahraga. Pada individu yang rutin berolahraga jantungnya berkontraksi lebih sedikit untuk memompakan darah dengan volume yang sama. Olahraga dapat menyebabkan penurunan denyut jantung, oleh karena itu olahraga secara teratur akan menurunkan cardiac output, yang menyebabkan terjadinya penurunan tekanan darah pada penderita hipertensi. Peningkatan efisiensi kerja jantung mengakibatkan penurunan tekanan darah sistolik, sedangkan penurunan tahanan perifer berakibat pada penurunan tekanan diastolik (Sherwood, 2011).

Kegiatan latihan yang mudah dilakukan seperti brisk walking excercise dapat dilakukan selama 1 minggu untuk mengontrol tekanan darah tinggi dengan mudah, dan responden dapat melakukan pola hidup yang sehat tanpa takut tekanan darah meningkat. Brisk walking exercise dapat dilakukan minimal 3 kali dalam seminggu untuk tetap menjaga tekanan darah tetap normal.

\section{KESIMPULAN}

Implikasi

Terdapat pengaruh yang signifikan dari pemberian brisk walking exercise terhadap penurunan tekanan darah sistolik dengan dan tekanan darah diastolic lansia. Temuan penelitian ini dapat dijadikan sebagai salah satu prosedur alternatif keperawatan mandiri pemberian brisk walking exercise sebagai salah satu penatalaksanaan untuk pasien hipertensi.
Keterbatasan

Peneliti dalam memberikan intervensi tidak mengikutsertakan usia lansia yang lebih dari 70 tahun. Belum terlihat perbedaan pemberian brisk walking exercise pada lansia awal dan lansia dengan usia lebih dari 70 tahun.

\section{DAFTAR PUSTAKA}

Andria, K. M. (2013). Hubungan Antara Perilaku Olahraga, Stress, dan Pola Makan Dengan Tingkat Hipertensi Pada Lanjut Usia di Posyandu Lansia Kelurahan Gebang Putih Kecamatan Sukolilo Kota Surabaya. Jurnal Promkes2, 1(2), 111-117.

Armilawaty, Amalia, H., \& Amiruddin, R. (2007, December 8). Hipertensi dan faktor risikonya dalam kajian epidemiologi: New Paradigm for Public Health. Retrieved from https://ridwanamiruddin.wordpress.co m/2007/12/08/hipertensi-dan-faktorrisikonya-dalam-kajian-epidemiologi/

Badan Penelitian dan Pengembangan Kesehatan. (2018). Hasil Utama RISKESDAS 2018. Jakarta.

Dinas Kesehatan Provinsi NTB. (2019). Profil Kesehatan NTB 2018. Mataram.

Kementerian Kesehatan RI. (2016). Profil Kesehatan Indonesia 2015. Jakarta.

Kowalski, R. E. (2010). Terapi Hipertensi : Program 8 Minggu Menurunkan Tekanan Darah Tinggi dan Mengurangi Risiko Serangan Jantung dan Srtoke Secara Alami. Bandung: Qanita.

Nugroho, W. (2012). Keperawatan Gerontik \& Geriatrik (3rd ed.). Jakarta: EGC.

Nursalam. (2016). Metode Penelitian Ilmu Keperawatan. Jakarta: Salemba Medika.

Pradono, J. (2010). Faktor- Faktor Yang Mempengaruhi Terjadinya Hipertensi di Daerah Perkotaan (Analisis Data Riskesdas 2007). Gizi Indonesia, 33 (1), 59-66.

Puskesmas Ampenan. (2019). Data Penyakit Tidak Menular. Ampenan.

Sherwood, L. (2011). Fisiologi Manusia (6th ed.). Jakarta: EGC. 
Sri Mulia, dkk : Pengaruh Brisk Walking Exercise terhadap Penurunan Tekanan Darah pada Lansia

Suranti, I. (2017). Pengaruh Brisk Walking Exercise Terhadap Penurunan Tekanan Darah Pada Pasien Hipertensi di Puskesmas Andalas Tahun 2016. Universitas Andalas.

WHO. (2019). Hypertension. Retrieved from https://www.who.int/news-room/ fact-sheets/detail/hypertension

Wijayakusuma, H. (2008). Ramuan Lengkap Herbal Taklukkan Penyakit. Jakarta: Pustaka Bunda. 